\title{
ERTIMBANGAN KEWAJIBAN PRINSIP DEKLARATIF PADA HAK CIPTA FOTOGRAFI JURNALISTIK MELALUI MEDIA INTERNET
}

\author{
Oleh : \\ Karuniawan Nurahmansyah \\ E-mail : awanhansyah88@gmail.com
}

\begin{abstract}
The principle of declarative at the applications have to give priority to the announcement early so that the creation of and find refuge, related on permasalah that occurs especially the journalist they still have not realized and understand the importance of copyright protection on works journalistic photography, copyright protection arranged on act number 28 years 2014 on copyright. In general to get the protection of the law on the rights of copyright is to do recording the creation of on works copyright, but the registration of the work of the creation of not as evidence that of that work have received the protection of the law, it is just that as the notions of the preliminary to the process of evidence copyright sengeketa when your words come true. Journalist did not yet fully understand his creatures that a work centers on the rights of journalists and the importance of moral right moral soul because is the creator of the journalis.
\end{abstract}

Keywords: The declarative, legal protection, copyright, photography journalistic 


\section{PENDAHULUAN}

\subsection{Latar Belakang}

Terkait pada pengertian menurut Intellectual Property Rights (IPR) mengartikan pada Bahasa Indonesia bahwamemiliki istilah Hak Kekayaan Intelektual, yang selanjutnya disebut (HKI). Pada peraturan perundangan menggunakan istilah HKI sebagai istilah resmi dalam perundang-undangan Indonesia.

HKI menjelasakan pada bendatidak berwujud merupaka hasil dari kegiatan intelektual manusia yang harus dan wajib untuk dituangkan pada bentuk karya ciptaan dan atau penemuan. Terkait daya cipta pada ilmu pengetahuan, dan atau seni lainya,dan pada teknologi. Pada segi hukum, bahwa yang mendapatkan perlindungan oleh hukumadalah HKI, bukan benda material yang masih dalam bentuk jelmaan atau ide. Permasalahannya pada HKIterhadap hakeksklusifyang hanya ada dan melekat pada pemilik karya cipta dan atau pemegang hak. ${ }^{1}$

Dunia fotografi keberadaannya mengalami perkembangan yang sangat cepat,kemajuan pada teknologi yang pesat berkembang menjadi eradunia fotografi digital. Penggunaan kaset atau disebut

\footnotetext{
${ }^{1}$ Abdul Kadir Muhammad, Kajian Hukum Ekonomi Hak Kekayaan Intelektual, (B a ndung; PT.Citra Aditya Bakti, 2001), hlm 1.
}

dengan media Filmsudah tidak ada menggunakannya, melainkan dalam bentuk filedigitalhal inilah yang semakin memudahkannya setiap individu untuk menggandakan dan mencetak hasilnya. Dengan sangat mudahnya untuk digandakan dan ataudiambil oleh setiap individu untuk kepentingan pribadi maupun kepentingan umum dan dimanfaatkan dalamberbagai kepentingan tanpa sepengetahuan pemiliknya, dan akan timbul masalah-masalah hukum khusunya pada bidang hak cipta.

Terkait pada pemberian manfaat HKI dan penggunaan pada internet berakibat berupa pelanggran terhadap karya cipta hal ini yang sangat dirugikan adalah pencipta. Terkait pada internet dengan mudahnya menggandakan akan timbul masalahmasalah HKI. Dikarena HKI memang berperan penting pada kehidupan dunia modern ini yang sangat berkaitan erat pada bidang teknologi, bidang ekonomi, maupun bidang pada seni budaya. Terkait hak cipta terhadap karya cipta digital seperti pada karya fotografi jurnalistik harus mendapat perlindungan hukum, dikarenakan setiap hasil karya pencipta yang dihasilkan pengorbanan tenaga, pikiran dan waktu bahkan dalam bentuk biaya yang tidak sedikit serta pengetahuan dan semua bentuk idealisme dari 
seseorang. $^{2}$

Hak cipta fotografi digital, dan program atau dokumen dan karya cipta non digital seperti pada karya bentuk seni rupa, dalam bentuk lukisan, dalam bentuk ukiran, dalam bentuk seni pahat, dalam bentuk patung, dalam bentuk sketsa, dikarenakan hanya merujuk pada karya cipta saja. Terkait pada spesifikasi dalam bentuk karya cipta digital yang dibuat buat dengan bantuan media digital yaitu beruapa karya intelektual misal pada CD maupun E-Book merupaka bentuk hasil ciptaan digital, hal ini lah yang menjadi permasalah hukum pada bidang hak cipta digital.

Terkiat pada kemajuan zaman yang erat dengan era globaliasi, perlindungan terhadap karya cipta dan hak cipta dan yang terutama pada karya cipta digital tidak mudah untuk dilakukan. Semakin banyaknya pembajakan didunia digital maupun yang bukan digital yang pada prinsipnya adalah memperbanyak dan atau menggandkan karya cipta tanpa seizin pencipta dan atua pemegangi hak cipta. Terkait pada bentuk karya digital permasalahan pembajakan ini lebih rumit, dikarenakan karya cipta digital mudah untuk didapatkan dengan cara copy atau digandakan. Terkait dengan penggandaan

\footnotetext{
2 Sutan Remy Syahdeini, Kejahatan \& Tindak Pidana Komputer, (Jakarta; Pustaka Utama Grafiti, 2009), hlm, 59.
}

terhadap karya cipta yang dapat dikatakan sulit untuk meniru ialah dalam bentuk karya seperti halnya karya seni patung maupun dalam karya seni lukisan, dalam bentuk ukiran, dan lain-lain, pada penggandaan ini sangat diperlukan waktu dan upaya untuk menganddakan dikarenakan bentuk karya yang berupa fisik ini mempunyai nilai yang khas disetiap karya ciptaanya. Terkait pada permasalahan ini tidak berlaku di bagi karya digital. Seperti pada karya fotogarfi junalistik. $^{3}$

Khususnya foto jurnalistik adalah bagian penting dalam pemberitaan suatu informasi oleh media massa, foto jurnalistik memegang peranan untuk menyempurnakan informasi yang hendak disiarkan kepada masyarakat luas. Dikatakan demikian karena kadangkala masyarakat kesulitan dalam memahami berita, sehingga dalam hal inilah foto jurnalistik dapat menjadi jawaban atas kebutuhan masyarakat tersebut. ${ }^{4}$ Terkait dengan pentingnya peran foto jurnalistik dalam suatu pemberitaan, maka foto kerapkali menghadirkan permasalahan sehubungan dengan hak kepemilikan dari foto tersebut. Biasanya pihak yang bertikai adalah pewarta foto dengan media. Jika

\footnotetext{
3 Soelistyo dan Henry, Pelanggaran Hak Cipta Plagiat Dan Etika, (Yogyakarta ; Kanisius, 2011), hlm 2

${ }^{4}$ Hikmat dan Purnama Kusumaningrat, Jurnalistik: Teori dan Praktik,, (Bandung; Remaja Rosdakarya, 2005), hlm 21
} 
ditarik garis lebih jauh, pangkal permasalahan itu kemungkinan besar adalah mengenai keuntungan, biasanya dalam bentuk materiil. $^{5}$

Menjamurnya praktik plagiarisme di kalangan jurnalis ini sangat berdekatan dengan aktivitas penjiplakan suatu karya sendiri telah menjadi fenomena yang cukup akrab khususnya di lingkungan para jurnalis. Plagiarisme seolah menjadi semacam virus yang mulai menjalar ke berbagai lini profesi termasuk di kalangan jurnalis profesi jurnalis menjadi rentan terhadap perilaku plagiat mengingat output yang dihasilkan adalah sebuah karya jurnalistik dalam bentuk gambar / foto yang bisa dijiplak atau ditiru oleh orang lain. Penjiplakan karya yang dilakukan para jurnalis tersebut seringkali dilakukan oleh sesama jurnalis. Salah satunya adalah dengan mengambil atau menjiplak informasi untuk dijadikan karya jurnalistik yang disebarluaskan di media massa. Aktivitas plagiat di kalangan jurnalis ini sangat disayangkan mengingat hal tersebut bertentangan dengan kode etik jurnalistik. Sesuai dengan pasal 13 Kode Etik Jurnalistik Wartawan Indonesia disebutkan: "Para jurnalis tidak boleh melakukan tindakan plagiat, dalam menggutip berita, maupun tulisan, dan atau gambar tanpa menyebut sumbernya"

${ }^{5}$ Ibid, hlm 23
Selain bertentangan dengan etika, penjiplakan karya jurnalistik juga merupakan bentuk pelanggaran UUHC 2014. Praktik plagiasi tersebut kini bahkan semakin mudah dilakukan dengan berbagai kemajuan teknologi dan perangkat informasi. Teknologi salah satunya telah merubah pola kerja jurnalis dalam mengumpulkan informasi menjadi berita atau karya foto jurnalistik. Teknologi juga mempermudah sistem kerja redaksi karena reporter atau wartawan di lapangan tidak melulu harus mengirimkan karyanya secara langsung di kantor tetapi bisa dilakukan hanya dengan mengirimkan melalui email atau milis perusahaan media yang bersangkutan. Tentu saja, kemudahan tersebut memberikan dampak positif dalam menunjang kinerja jurnalis. Pada satu sisi, seringkali kemudahan akses dan pertukaran informasi justru membuat wartawan malas untuk mengumpulkan informasi langsung dari sumbernya. Pada perkembangannya, wartawan tanpa segan cukup melakukan copy paste press release atau karya dari jurnalis lain. Berita hasil copy paste tersebut tinggal dipercantik dengan menambahkan kode pada tulisan yang seolah mengatasnamakan karyanya. ${ }^{6}$

Proses kerja jurnalis di lapangan dalam mengumpulkan informasi menjadi berita, ternyata juga ikut mempengaruhi

${ }^{6} \mathrm{Ibid}, \mathrm{hlm} 25$ 
berkembangnya perilaku plagiat khususnya fotografi jurnalistik. Jurnalis bekerja dengan memiliki pos-pos bidang tertentu sesuai dengan rubrik yang menjadi tanggung jawabnya. Misalnya wartawan menjadi dikelompokkan dalam bidang ekonomi, politik, pemerintahan, pendidikan, seni budaya dan lainnya.

Pengelompokan inilah yang menyatukan jurnalis dalam bidang yang sama saat mencari sumber berita. Kesamaan bidang yang diampu tersebut pada akhirnya berkaitan pula dengan sumber berita yang sama atau berbagai kegiatan yang sama yang dicari jurnalis untuk menghasilkan berita. Para jurnalis tidak jarang saling membantu dan bertukar informasi. Dari sekedar pertukaran agenda biasa, pertukaran statement narasumber yang diwawancarai hingga bahkan pertukaran karya jurnalistik antar wartawan dari media yang berbeda. ${ }^{7}$

Seringkali wartawan dengan begitu saja mengambil karya jurnalistik wartawan lain yang biasanya telah ditayangkan di media online, untuk dijiplak dan dibuat berita di media cetak. Pengalaman dijiplak karyanya oleh jurnalis lain ini tentu saja banyak dialami oleh wartawan media online. karakteristik media yang real time, jurnalis media online dituntut untuk dengan cepat menyiarkan hasil liputan di

${ }^{7}$ Sirikit Syah, Rambu-Rambu Jurnalistik, (Jakarta; Sukma Citra, 2001), hlm 29. lapangan untuk ditayangkan dalam website berita online. Kecepatan penyampaian informasi inilah yang seringkali banyak dimanfaatkan wartawan baik cetak maupun elektronik untuk mendapatkan data dengan mudah dan mengutakatik karya jurnalis online menjadi berita miliknya, tidak jarang wawancara eksklusif sekalipun dapat dengan mudah dijiplak. ${ }^{8}$

Permasalahan yang berkembang saat ini adalah lemah dan rendahnya tingkat pemahaman masyarakat tentang bentuk karya cipta dan hakcipta, dikarenakan sikap dan keinginan untuk memperoleh keuntungan materiil. Salah satu pelanggaran hak cipta atas karya fotografi jurnalistik yang terjadi adalah antara media masaa Inewsdengan seorang pencipta karya fotografi jurnalistik yang menyatakan bahwa ia adalah pencipta atas karya tersebut dan merasa karya fotonya digunakan, dipublikasikan, diperbanyak tanpa seizin pencipta dan tanpa sepengetahuan pemegang hak cipta ialah media tempat pewarta tersebut bekerja dan tidak mencantumkan nam aasli dari pencipta atas karya fotografi tersebut.

Prinsip deklaratif ini mempunyai kekurangan untuk melindungi para pencipta dalam artian bahwa pencipta harus menggunakan prinsip deklaratif untuk mendapatkan perlindungan hukum.

\footnotetext{
${ }^{8}$ Ibid,hlm 30.
} 
Sebagai contoh kasus yang di alami oleh seorang jurnalis Inews yang karya nya digunakan oleh jurnalis lain tanpa seizin pencipta dikarenakan jurnalis Inews tidak menjalankan prinsip deklaratif, foto jurnalistik yang digunakan oleh sesama profesi jurnalis ialah foto jurnalistik terhadap bencana alam yang terjadi di kota kediri 14 Februari 2014, saat gunung kelud meletus, jurnalis Inews memotret detikdetik terjadinya letusan gunung kelud dengan jarak $5 \mathrm{~km}$ dari letusan, setelah mendapatkan hasil memotretnya jurnalis Inews kembali menuju tempat pengungsian di dalam perjalanan nya dia tidak mengetahui bahwa memory card yang berada dalama camera digitalnya terjatuh tanpa sepengetahuan dia. Ternyata tanapa sepengetahuan jurnalis Inews ada seorang jurnalis lain yang meng upload hasil karrya tersebut sebagai berita di media online tanpa seizin jurnalis Inews. ${ }^{9}$

Terkait hal ini juga berdampak pada keinginan jurnalis untuk berupaya melindungi hasil karya mereka tersebut agar tidak dimanfaatkan oleh orang yang mencari keuntungan pribadi tanpa meminta izin terlebih dahulu pada siapa yang sudah menciptakannya pertama kali. HKI muncul pada upaya untuk memberikan perlindungan dan upaya pengakuan bagi

\footnotetext{
${ }^{9}$ www.Inews.com/pelanggaranhakciptafotografijurn alistik Diakses pada tanggal 08 November 2017, pukul 13.00 Wib.
}

setiap orang yang mampu menggunakan ide pikirannya dan menuangkannya menjadi hasil karya cipta yang berwujud yang dapat dinikmati oleh diri pribadi maupun orang lain yang menggunakan karya cipta tersebut. Penerapan terhadap penggunaan hak cipta rentan dengan pelanggaran yang dilakukan sering dilakukan oleh pihak yang tidak bertanggung jawab demi meraup keuntungan pribadi dengan meniru atau mendompleng karya ciptaan terdahulu. Hal ini menyebabkan orang malas untuk mengembangkan kreativitas mereka khususnya terhadap karya fotografi jurnalistik bentuk pelanggaran hak cipta umumnya yang sering terjadi adalah penggandaan dengan cara ciptaan yang diperbanyak dengan tanpa seizin seoarang pencipta dan atau pemegang hak cipta yang biasa disebut dengan pembajakan atau plagiat.

Seseorang apabila menggunakan sebuah karya foto jurnalistik untuk suatu kepentingan dan tanpa meminta izin kepada pencipta, merupakan bentuk pelanggaran pada hak cipta. Ciptaan yang dilindungi khususnya karya fotografi terdapat dalam Pasal 40 ayat 1 tentang Hak Cipta huruf (K) Undang - Undang Nomor 28 Tahun 2014 yang selanjutnya disebut dengan (UUHC 2014).

\subsection{Permasalahan}

Berdasarkan uraian diatas, isu hukum yang akan dibahas dalam penelitian ini 
adalah apa yang menjadi dasar pertimbangan kewajiban prinsip deklaratif pada hak cipta fotografi jurnalistik melalui media internet?

\section{METODE PENELITIAN}

Pada suatu penulisan harus mempergunakan metode penulisan yang tepat karena hal tersebut sangat diperlukan dan merupakan pedoman dalam rangka mengadakan analisis terhadap data hasil penelitian. Ciri dari karya ilmiah di bidang hukum adalah mengandung kesesuaian dan mengandung kebenaran yang dapat dipertanggung jawabkan. ${ }^{10}$ Mengadakan suatu penelitian ilmiah mutlak menggunakan metode, karena dengan metode tersebut. Pada penyelidikan yang akan berlangsung pada suatu rencana tertentu, artinya peneliti tidak bekerja secara acak-acakan melainkan setiap langkah yang diambil harus jelas dan atau harus tepan serta pembatasan-pembatasan agar tidak menyesatkan dantidak terkendalikan. $^{11}$

Pada tipe penelitian yang digunakan pada penelitian ini menggunakan metode Yuridis Normatif (Legal Research). Pada

\footnotetext{
${ }^{10}$ Peter Mahmud Marzuki, Penelitian Hukum, Edisi Revisi Cetakan ke 9, (Jakarta ; Kencana Prenada Media Group 2014), hlm, 43

${ }^{11}$ Johnny Ibrahim, Teori dan Metodologi Penelitian Hukum Normatif. Edisi Revisi, Cetakan II, (Malang ; Banyumedia Publishing 2006), hlm 294
}

penelitian hukum metode untuk menemukan aturan hukum yang ada, yang akan nantinya dijadikan sebagai pedoman dan atau dasar pada prinsip hukum, dan juga mengadopsi dari doktrin-doktrin hukum untuk menjawab permasalahan hukum.. ${ }^{12}$

Pendekatan penelitian Ini menggunakan 3 pendekatan yaitu berupa Pendekatan perundang-undangan (Statute Approach), dilakukan dengan cara menelaah semuaperaturan perundangan dan regulasi harus bersangkut paut pada permasalahan hukum.Pendekatan Konseptual (Conseptual Approach), merupakan pendekatan dengan merujuk pendapat para ahli hukum dan pada prinsip-prinsip hukum, dengan mempelajari pendapat para ahli dalam ilmu hukum,Pendekatan Sejarah (history), merupakan pendekatan yang mempunyai tujuan untuk mengetahui aturan hukum dari waktu ke waktu pada rangka untuk memahami filosofi dari aturan dan untuk mempelajari perkembangan aturan hukum yang penulis kaji. $^{13}$

Bahan hukum merupakan sarana untuk suatu penulisan yang digunakan dan untuk memecahkan isu hukum yang sekaligus memberikan preskripsi dalam aturan yang ada. Sumber penelitian hukum yang digunakan pada penelitian tesis ini

\footnotetext{
12 Peter Mahmud Marzuki, Op Cit, hlm 60

${ }^{13}$ Ibid, Hlm 14
} 
adalah sumber penelitian berupa bahan hukum primer, bahan hukum sekunder: ${ }^{14}$

1) Bahan Hukum Primer

Berbagai peraturan perundangundangan dan kepustakaan hukum dapat ditemukan istilah istilah lain untuk menyebutkan istilah peraturan perundang undangan, ${ }^{15}$ Bahan hukum primer yang digunakan penulis dalam penulisan tesis ini yang meliputi sebagai beriku :

a. Undang-UndangNo 19 Tahun 2016tentang Informasi Dan Traknsaksi Elektronik

b. Undang-UndangNo 40 Tahun 1999 tentang Pers

c. Undang-UndangNo 28 Tahun 2014 tentang Hak Cipta

2) Bahan Hukum Sekunder

Bahan hukum sekunder merupakan bentuk publikasi tentang hukum meliputi buku-buku, teks hukum, kamus-kamus hukum, jurnal-jurnal hukum, bahan- bahan cetakan ( print out ). ${ }^{16}$

Analisa bahan hukum merupakan metode atau cara yang digunakan oleh penulis dalam menentukan jawaban atas permasalahan yang dibahas. Langkahlangkah yang dilakukan dalam penulisan penelitian hukum, yaitu: Pertama, mengidentifikasi fakta hukum dan mengeliminir hal-hal yang tidak relevan

\footnotetext{
${ }^{14}$ Ibid. hlm, 181 .

15 Dyah Ochtorina Susanti, A'an efendi, Penelitian Hukum, (Jakarta; Sinar Grafika, 2014) hlm 53

${ }^{16}$ Ibid, hlm, 87
}

untuk menetapkan isu hukum yang hendak dipecahkan; kedua, bahan-bahan hukum yang sekiranya dipandang dapat menjadi acuan juga terhadap bahan-bahan non hukum; ketiga, metode yang dilakukan dengan menelaah pada permaslahan hukum untuk mencari jawaban dari permasalahan tersebut, keempat, kesimpulan pada bentuk argumentasi dalam menjawab permaslahan hukum, kelima, memberikan pendapat dan saran agar nantinya kedepan dalam pembangunan nasional khusunya pada bidang hukum lebih baik. ${ }^{17}$

\section{PEMBAHASAN}

\subsection{Dasar Pertimbangan Kewajiban \\ Prinsip Deklaratif Pada Hak Cipta}

\section{Fotografi Jurnalistik Melalui Media}

\section{Internet}

Tujuan hukum secara umum adalah menegakkan ketertiban umum dan keadilan. $^{18}$ Merujuk pada pendapat tersebut maka tujuan hukum dalam hukum perdata khususnya di bidang hak cipta untuk mendapatkan perlindungan hukum dan kepastian hukum atas pemanfaatan dibidang hak cipta. Berkaitan dengan hak cipta kepastian hukum atas pemanfaatan hak ciptaialah untuk mendapatkan hak

\footnotetext{
${ }^{17}$ Peter Mahmud Marzuki. Op.Cit hlm, 213.

${ }^{18}$ Barda Nawawi Arif, Bunga Rampai Hukum Pidana, (Bandung ; PT. Citra Aditya Bakti 2002), h1m 14
} 
ekonomi yang diperuntukan oleh pencipta, ciptaan mempunyai nilai ekonomis berdasarkan Pasal 8 UUHC 2014 tentang Hak Cipta Menyebutkan "Hak ekonomi merupakan hak eksklusif pencipta atau pemegang hak cipta untuk mendapatkan manfaat ekonomi dari ciptaannya."

Tujuan hukum dibidang hak cipta untuk mendapatkan perlindungan khusunya bagi pencipta sudah diatur dalam Pasal 40 ayat 1 huruf (k) UUHC 2014.

Fungsi hukum secara umum, menurut Soerjono Soekanto adalah memberi pedoman pada masyarakat tentang bagaimana mereka harus bersikap dan bertingkah laku, menjaga keutuhan masyarakat, memberikan pegangan pada masyarakat untuk melakukan pengendalian sosial. ${ }^{19}$ Berkaitan mengenai pembahasan dalam penelitian ini fungsi hukum dalam hak cipta yaitu untuk memberikan manfaat secara penuh terhadap pencipta khusunya fotografi jurnalis, dari manfaat itu seorang jurnalis akan mendapatkan manfaat dari ciptaan yaitu berupa manfaat secara ekonomi dari hasil ciptaannya tersebut

Berdasarkan teori yang di kemukan oleh Jeremy Betham mengenai teori utilitarisme, pada prinsip ini dalam memberikan kebahagiaan hendaknya pada suatu perundang-undangan itu selalu

19 Soerjono Soekanto, Kesadaran Hukum dan Kepatuhan Hukum, (Jakarta; Rajawali 1982), hlm 9 meletakkan kemanfaatan sebagai tujuan utama hukum. Teori ini bertujuan mewujudkan yang sesuai dengan daya guna, hukum barulah diakui sebagai hukum jika ia memberikan kemanfaatan yang sebesar-besarnya terhadap sebanyakbanyaknya orang. ${ }^{20}$

Merujuk pada pendapat tersebut diatas bahwa jurnalis masih belum mendapatkan kemanfaatan dari ciptaannya yaitu hak ekonomi yang biasa dikaitkan dengan honor atau upah. banyak sekali jurnalis yang tidak mengerti tentang aturan mengenai hak ekonomi ciptaan. Salah satu contoh yang terjadi pada prakteknya ialah seorang jurnalis Inews, jurnalis mencari berita untuk disampaikan kepada khalayak agar mengetahui informasi yang diberikan oleh jurnalis dengan media foto sebagai pelengkap isi berita tersebut, namun yang terjadi setelah berita telah sampai kepada masyarakat, jurnalis yang sebagai pencipta tidak mendapatkan manfaat dari hasil ciptaanya dalam artian jurnalis Inews memberikan berita ke kantor tempat jurnalis berkerja, tetapi media lain juga menggunakan karya tersebut tanpa memberikan hak ekonomi kepada jurnalis, yaitu berupa upah atau honor dikarenakan jurnalis kurang mengetahui bahwa hak ekonomi telah diatur. $^{21}$

\footnotetext{
${ }^{20}$ Satjipto Rahardjo, Op Cit, hlm 48

21 Surya Adiningrat, Hak Cipta Fotografi, (Semarang ; Paramita 2013), hlm 56
} 
Berkaitan dengan mengenai pembahasan dasar pertimbangan kewajiban prinsip deklaratif, didalam risalah sidang pembentukan Rancangan UUHC 2014 tidak menjelaskan mengenai kewajiban prinsip deklaratif, didalam rapat hanya banyak membicarakan mengenai perlindungan, jangka waktu perlindungan, royalti, managemen kolektif, hak ekonomi dan hak moral untuk pencipta. Tidak ada penjelasan mengenai definisi mengenai prinsip deklaratif.

Agus Sarjono menyampaikan pendapat dalam sidang mengenai "pengumuman dan pendistribusian doktrin itu yang disebut pengumuman itu ada 2 katagori, pertama, pengumuman dalam arti making available for public. Artinya, orang bisa beli, orang bisa menikmati ciptaan. Itu biasanya dalam bentuk distribusi dalam bentuk penjualan, dalam bentuk penyewaan. Itu termasuk dalam katagori pengumuman,katagori kedua adalah bergantung kepada bentuk-bentuk ciptaannya yaitu kalau misalnya karya ciptanya bentuknya musik maka salah satu bentuk pengumuman adalah performing atau memperdengarkan kalau itu musik. Kalau itu lukisan, mendisplay. Kalau itu 3 dimensi patung, itu memajang, ya display juga. Jadi 2 katagori itu belum jelas di dalam RUU, padahal implikasinya sangat luas. Mengapa? Karena di dalam UndangUndang atau di dalam doktrin hak cipta itu ada pihak-pihak yang memang menjadi pemegang hak pengumuman dalam arti distribusi dalam arti pengumuman itu berbeda. $" 22$

Menurut Rachmadi Usman, perlindungan hak cipta yang diberikan secara langsung dan atau otomatis setelah ciptaan tersebut dibuat dan berbentuk secara utuh dan nyata. Perlindungan langsung harus diwujudkan dan dituangkan dengan pemberian hak eksklusif dan menjalakan prinsip deklaratif. ${ }^{23}$ Pencipta harus mengutamakan pengumuman awal agar khalayak mengetahui bahwa ciptaan tersebut sudah dipublikasikan, tidak mewajibkan untuk mendaftarkan ciptaan. Sedangkan prinsip deklaratif adalah sistem yang tidak mengharuskan adanya pencatatan, akan tetapi pencipta tetap memiliki perlindungan langsung ketika ciptaan selesai dibuat dan berbentuk nyata, pencipta dapat mengontrol agar tidak ada seorang pun yang memanfaatkan haknya tanpa seizin pencipta. Yaitu sebagai berikut; ${ }^{24}$ Dasar utama pertimbangan pada prinsip deklaratif hak cipta diantaranya: ${ }^{25}$

\footnotetext{
22 Risalah Undang - Undang Nomor 28 ahun 2014 Tentang Hak cipta, disampaikan digedung DPR RI, Jakarta, 13 Februari 2014, hlm 5

${ }^{23}$ Rachmadi Usman, Hukum, Hak Atas Kekayaan Intelektual: Perlindungan dan Dimensi Hukumnya di Indonesia, (Bandung ; PT Alumni 2003), hlm 13

${ }^{24}$ Ibid, hlm 20

${ }^{25}$ Eddy Damain, Hukum Hak Cipta, ( Bandung;PT Alumni 2014), hlm 146
} 
1. Dasar orisinalitas (Original). Merupakan bentuk bahwa suatu ciptaan orisinalitas menjadi acuan utama untuk sebagai alat bukti secara factual bahwa karyanya benar-benar asli, keaslian dari suatu ciptaan atau karya HKI dan harus benar-benar terpenuhi.

2. Dasar bentuk fisik (Phisycal Form). Merupakan bentuk yang sudah tertuang dalam bentuk nyata.

3. Diwujudkan pada media tertentu (Tangible Media). Merupakan bentuk yang telah diwujudkan pada suatu media yang dapat disimpan dengan tujuan supaya dapat dibaca, didengar, atau dilihat serta dapat dinikmati oleh masyarakat luas

4. Jangka Waktu (Term Duration). Merupakan bentuk perlindungan yang diberikan oleh undang-undang.

Terkait pemerintah dalam hal ini Menteri Hukum dan Hak Asasi Manusia juga menyelenggarakan suatu pencatatan ciptaan, dapat dipahami bahwa fungsi penyelenggaraan pendaftaran hak cipta dimaksudkan untuk memudahkan pencipta pada pembuktian bila terjadi sengketa mengenai HKI. Terkait pencipta sudah mencatatkan hasil ciptaannya dan mendapatkan surat pencatatan pada ciptaan maka surat tersebut sudah dapat digunakan bukti awal kepemilikan suatu ciptaan. Pada saat pendaftaran itu sendiri tidak melahirkan perlindungan hak cipta,akan tetapi melalui pendaftaranlahakan mempermudah bagi orang yang ingin mendaftar untuk membuktikan bahwa dirinyalah "pemegang" hak cipta tersebut.

\subsection{Penggunaan Prinsip DeklaratifPada}

Hak Cipta Fotografi Jurnalistik Melalui Media Internet Merupakan

\section{Hak Moral}

Hak moral yang berprinsip bahwa identitas diri (self indentity) manusia terpancar dari karya atau ciptaannya berpijak pada pemikiran Georg Wilhelm Friedrich Hegel. ${ }^{26}$ Hak moral merupakan bagian dari jiwa penciptanya sehingga hanya dapat pencipta yang berhak untuk mengubah ciptaannya dan menentukan untuk dipublikasikan kepada umum. ${ }^{27}$ Hak moral yang kemudian diberikan kepada pencipta atas ciptaannya melahirkan doktrin droit d'auteur yang mengandung beberapa hak, yaitu: ${ }^{28}$

1. Droit de paternite, hak ini akan melekat selamanya pada pencipta meskipun ciptaannya sudah dialihkan kepemilikannya kepada pihak lain meskipun hak cipta telah berakhir dan pencipta telah meninggal dunia.

\footnotetext{
${ }^{26}$ Etty S Suhardo, Implikasi Undang-undang No. 19 Tahun 2002 Bagi Pengguna Hak Cipta, (Semarang ; fakultas hukum Universitas Semarang, 2003) hlm 7

${ }^{27}$ Ibid, hlm 12

28 Achmad Zen Umar Purba, Hak Kekayaan Intelektual Pasca TRIPs, (Bandung; PT Alumni 2007), hlm 67
} 
2. Droit de divulgation, merupakan pencipta memiliki hak untuk mereproduksi ciptaannya dan hak untuk menentukan mempublikasikan ciptaannya kepada khalayak.

3. Droit de au respect de I'integrity de I'ouevre, merupakan hak menuntut dan mendapatkan ganti rugi materil atas hak ciptanya bila dilanggar orang lain

4. Droit de retrait et de repentir, merupakan hak pencipta untuk menarik ciptaannya dari publikasi dengan berbagai alasan pribadi.

Terkait dengan konsep hak moral memberikan bentuk pengakuan, yang mungkin lebih tinggi daripada pengakuan lainnya berupa penghargaan penghormatan dan kekaguman. ${ }^{29}$ Terkait dengan hak moral yang sebenarnya bertujuan untuk mempertahankan identitas dan atau integritas pencipta dengan ciptaannya dalam rangka mempertahan-kan keutuhan dan keaslian dari ciptaannya. ${ }^{30}$ Terkaitsalah satu hak moral adalah hak untuk mempublikasikan, terkait hak publikasi menjadi kewenangan dari pencipta, tetapi peranan publikasi amat penting mendorong perlindungan hak cipta.

Berkaitan mengenai pembahasan ini hak moral jurnalis yang dipublikasikan di media internet mempunyai hak moral yaitu

\footnotetext{
${ }^{29}$ Ibid, hlm 68

${ }^{30} \mathrm{Ibid}$, hlm 69
}

untuk mencantumkan identitas dari pencipta atau pemgang hak cipta, hak moral dari jurnalis sangatlah penting maka dari itu penting hak moral jurnalis untuk mendapatkan perlindungan dari plagiat, karena sangatlah mudah untuk mengambil data di media internet dengan mengcopy paste file tersebut sangat merugikan jurnalis apabila hak moral tidak dicantumkan identitas jurnalis.

Kasus yang terjadi khusunya dibidang jurnalis sesama rekan jurnalis banyak sekali terjadi plagiat dalam mengambil berita dikarenakan sangat lah mudah untuk memindahkan, perbuatan plagiat sesama jurnalis merupakan perbuatan melanggarhukum disamping itu plagiat juga bertentangan dengan kode etik jurnalis didalam pasal 15 ayat 2 huruf (b) Undang-Undang Nomor 40 Tahun 1999 Tentang Pers yang menjelasakanyang pada intinya pelaksaaan kode etik jurnalis harus benar-benar dijalankan agar dalam menjalakan profesinya jurnalis tidak berhadapan dengan bentuk pelanggaran hukum yang terkait dengan hak cipta.

Terkait hak moral yang mempunyai sifat manunggal hak cipta dengan penciptanya, tidak diperkenankan untuk melakukan perubahan terhadap suatu karya cipta selain oelh pencipta, baik itu mengenai isi judul, dan lain -lain, terkait demikian hanya dapat dilakukan orang lain apabila mendapatkan izin dari pencipta 
atau ahli waris jika pencipta sudah meninggal dunia. Pencipta atau ahli warisnya saja yang mempunyai hak unuk mengandakan perubahan-perubahan pada ciptaan-ciptaanya.

Akibat pelanggaran yang terjadi dan dilakukan oleh pihak yang tidak bertanggung jawab tersebut tidak hanya mematikan kreatifitas pencipta, namun juga merugikan jurnalis, hak moral jurnalis yang dilanggar maka akibat dari pelanggaran tersebut jurnalis berhak untuk meminta kerugian atas ciptaannya. Sebagai contoh yang terjadi, jurnalis Inews yang meliput berita dengan menggunakan media kamera untuk berkarya saat meliput terjadinya letusan Gunung kelud di kabupaten kediri dengan jarak $5 \mathrm{~km}$ dari puncak gunung kelud. ${ }^{31}$ Kemudian diunggah oleh jurnalis lain tanpa sepengetahuan dan ijin dari pencipta dan tidak mencantumkan identitas pencipta merupakan pelanggaran hak mora sekaligus merugikan jurnalis. Permasalahan akibat melanggar hak moral termasuk dalam pembajakan hak cipta ini sudah diatur dalam Pasall angka 23 UUHC 2014 menjelaskan bahwa: Pembajakanpada hak cipta adalah penggandaan hak cipta dan/atau produk hak terkait secara tidak sah dan pada pendistribusiannya barang hasil

\footnotetext{
${ }^{31}$ www.Inews.com/pelanggaranhakciptafotografijur nalistik Diakses pada tanggal 08November2017, pukul 13.00 Wib.
}

penggandaan dimaksud secara luas untuk memperoleh keuntungan ekonomi.

Terkait akibat hukum yang tejadi ialah pencipta dapat mengajukan gugatan ganti rugi kepada pengadilan niaga atas pelanggaran hak cipta. PadaUUHC 2014 , telah diatur tentang penegakan hukum hak cipta yang menetapkan perbuatan apa saja yang disebut sebagai tindak pidana hak cipta dan hak terkait. tuntutan hak keperdataan yang dapat diajukan dalam bentuk gugatan ke pengadilan niaga ataupun bentuk-bentuk tindakan hukum lainnya yang bertujuan untuk mencegah berlanjutnya suatu pelanggaran hak cipta.Terkait dengan ketentuan pidana akibat melakukan pelanggaran hak ekonomi dan hak moral sudah diatur dalam UUHC 2014 dalam bab XVIIdalam Pasal 112 ayat (1) mejelaskan : Bahwa siapapun yang dengan sengaja tanpa hak melakukan pelanggaran terhadap Hak Cipta dikenakan sanksi pidana penjara paling lama 2 (dua) tahun dan/atau denda paling banyak Rp. 300.000.000,-(tiga ratus juta rupiah).

Berdasarkan uraian diatas akibat hukum apabila melanggar hak moral pencipta bahwa ketentuan-ketentuan hukum yang mengatur tentang hak cipta dengan segala aspeknya sudah cukup memadai dan mendukung perlindungan hak cipta. Namun demikian meskipun ketentuan hukum telah cukup memadai untuk memberikan perlindungan terhadap 
hak cipta, sebagaimana telah disebutkan masih ada saja hambatan yang sering menghadang dalam upaya penegakan hukum tersebut sehingga perlu ada solusi atau pemecahan terhadap hambatan tersebut.

\section{PENUTUP}

\subsection{Kesimpulan}

Dasar pertimbangan prinsip deklaratif pada hak cipta yakni setelah ciptaan dalam bentuk nyata dan diumumkan tanpa harus melalui mekanisme pencatatan ciptaan, ciptaan harus orisinal, ciptaan harus diwujudkan, perlindungan hak cipta tidak perlu formalitas tertentu. terkait pertimbangan tersebut, yakni perlindungan diberikan tanpa formalitas tertentu, terkait pertimbangan kewajiban prinsip deklaratif dalam hak cipta tidak didasarkan pada pencatatan. Terkait pencatatan tidak dapat menentukan siapa penciptanya, tetapi hanya dapat berfungsi sebagai sangkaan awal suapaya prinsip deklaratif dapat diterapkan maka harus didorong adanya peranan publikasi dan pengumuman serta penilaian terhadap orisinalitas sebuah karya ciptafotografi jurnalistik.

\subsection{Saran}

Kepada Dewan Perwakilan Rakyat Republik Indonesia seharunya lebih tegas lagi dalam membuat peraturan di Indonesia, supaya upaya plagiat dapat diberantas dan upaya tersebut dapat pula dilakukan melalui sosialisasi dan penyuluhan mengenai hak cipta didalam implementasiUUHC 2014 yangdilakukan pada semuakalangan terkait khususnya para pencipta karya fotografi jurnalistik, berkaitan dengan dasar utama pertimbangan kewajiban dalam prinsip deklaratif khusunya pada pencipta karya fotografi jurnalistik masih mempunyai keterbatasan untuk menanggulangi pelanggaran hak cipta, maka dari itu perlindungan dan kepastian hak cipta jurnalistik tidak akan tercapai dengan maksimal apabila masyarakat masih lemah untuk memahami sistem prinsip deklaratif ini, seharusnya upaya pencegahan pelanggaran melalui media internet khususnya mengenai hak cipta ini dengan menitik beratkan pada edukasi kepada masyarakat tentang mengenai sistem deklaratif ini, selain itu pencegahan pelanggaran hak cipta fotografi jurnalistik dibidang teknologi dengan meningkatkan sistem keamanan informasi. 


\section{DAFTAR PUSTAKA}

\section{Buku Literatur}

Abdul Kadir Muhammad, 2001, Kajian Hukum Ekonomi Hak Kekayaan Intelektual, B andung; PT. Citra Aditya Bakti.

Achmad Zen Umar Purba, 2007, Hak Kekayaan Intelektual Pasca TRIPs, Bandung; PT Alumni.

Barda Nawawi Arif, 2002, Bunga Rampai Hukum Pidana, Bandung ; PT. Citra Aditya Bakti.

Dyah Ochtorina Susanti, A'an efendi, 2014, Penelitian Hukum, Jakarta; Sinar Grafika.

Eddy Damain, 2014, Hukum Hak Cipta, Bandung;PT Alumni

Hikmat dan Purnama Kusumaningrat, 2005, Jurnalistik: Teori dan Praktik, Bandung; Remaja Rosdakarya.

Johnny Ibrahim, 2006, Teori dan Metodologi Penelitian Hukum Normatif. Malang ; Banyumedia Publishing.

Peter Mahmud Marzuki, 2014, Penelitian Hukum, Jakarta; Kencana Prenada Media Group.
Rachmadi Usman, Hukum, 2003, Hak Atas Kekayaan Intelektual:

Perlindungan dan Dimensi Hukumnya di Indonesia, Bandung; PT Alumni.

Risalah Undang-Undang Nomor 28 ahun 2014 Tentang Hak cipta, disampaikan digedung DPR RI, Jakarta, 13 Februari 2014.

Sirikit Syah, 2001, Rambu-Rambu Jurnalistik, Jakarta ; Sukma Citra.

Soelistyo dan Henry,2011, Pelanggaran Hak Cipta Plagiat Dan Etika, Yogyakarta ; Kanisius.

Soerjono Soekanto, 1982, Kesadaran Hukum dan Kepatuhan Hukum, Jakarta; Rajawali

Surya Adiningrat, 2013, Hak Cipta Fotografi, Semarang; Paramita.

Sutan Remy Syahdeini,2009,Kejahatan \& Tindak Pidana Komputer, Jakarta; Pustaka Utama Grafiti.

\section{Perundang-undangan}

Undang-Undang Nomor 19 Tahun 2016 tentang Informasi Dan Traknsaksi Elektronik. 
Undang-Undang Nomor 40 Tahun 1999 tentang Pers.

Undang-Undang Nomor 28 Tahun 2014 tentang Hak Cipta.

\section{BIODATA SINGKAT PENULIS}

Karuniawan Nurahmansyah telah menyelesaikan pendidikan Sarjana Hukum pada Fakultas Hukum Universitas Jember dan Magister Hukum pada Program Magister Ilmu Hukum Fakultas Hukum, Universitas Jember tahun 2018. 